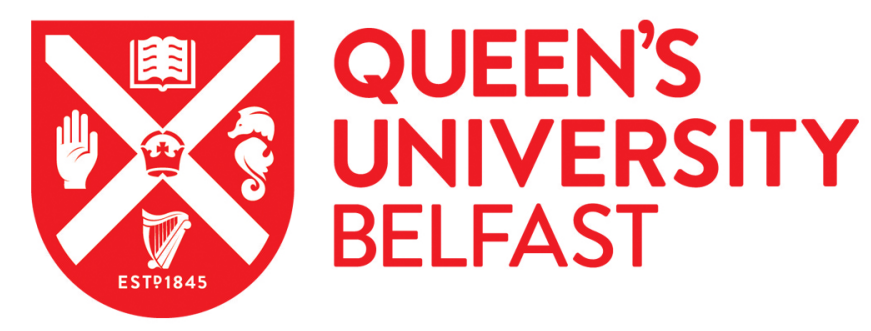

\title{
Uncovering the link between governance as an innovation process and socio-economic regime transition in cities
}

Simmons, G., Diez Giraldo, J. E., Truong, Y., \& Palmer, M. (2018). Uncovering the link between governance as an innovation process and socio-economic regime transition in cities. Research Policy, 47(1), 241-251. https://doi.org/10.1016/j.respol.2017.11.002

\section{Published in:}

Research Policy

\section{Document Version:}

Peer reviewed version

\section{Queen's University Belfast - Research Portal:}

Link to publication record in Queen's University Belfast Research Portal

\section{Publisher rights}

(C) 2017 Elsevier B.V. All rights reserved.

This manuscript version is made available under the CC-BY-NC-ND 4.0 license http://creativecommons.org/licenses/by-nc-nd/4.0/,which permits distribution and reproduction for noncommercial purposes, provided the author and source are cited.

\section{General rights}

Copyright for the publications made accessible via the Queen's University Belfast Research Portal is retained by the author(s) and / or other copyright owners and it is a condition of accessing these publications that users recognise and abide by the legal requirements associated with these rights.

Take down policy

The Research Portal is Queen's institutional repository that provides access to Queen's research output. Every effort has been made to ensure that content in the Research Portal does not infringe any person's rights, or applicable UK laws. If you discover content in the Research Portal that you believe breaches copyright or violates any law, please contact openaccess@qub.ac.uk. 


\section{Uncovering the link between governance as an innovation process and socio-economic regime transition in cities}

Corresponding Author:

Geoff Simmons

Queen's Management School

Queen's University Belfast

Riddel Hall

Stranmillis Road

Northern Ireland, United Kingdom

BT9 5EE

Tel. +442890974716

Fax. +442890974201

g.simmons@qub.ac.uk

Jorge Esteban Diez Giraldo

ESC Rennes School of Business

2 rue Robert d'Arbrissel

35065 Rennes Cedex

France

Yann Truong

University Bourgogne Franche Comté

Burgundy School of Business-CEREN

29 Rue Sambin, 21000 Dijon

France

Mark Palmer

Queen's Management School

Queen's University Belfast

Riddel Hall

Stranmillis Road

Northern Ireland, United Kingdom 


\begin{abstract}
A major proportion of the world's population will be located in cities by 2030 . With cities globally facing challenges due to the social exclusion of significant proportions of their populace, new thinking is needed on ways to correlate the competing socio-economic goals of various actors. This study sought to uncover the link between governance in cities as an innovation process and socio-economic regime transition towards a more equitable urban society. To do so, we draw on transition management thinking to consider urban regime transitions evolving in a temporal and incremental manner and in a multi-level context. We sought expansion from a delimited focus on socio-technical regimes in transition management literature to incorporate the notion of urban socio-economic regimes. This involved integrating aspects of reflexive governance and politics in a city context with a basic ontology of complex social systems and their evolutionary dynamics that underlies transition management approaches. Our focus is on learning by doing and experimentation as well as participation of citizens with other key city actors in a radically new process of mutual learning that creates social inclusion. The juxtaposition of national, city and community level interactions and their impact on socio-economic regime transition brings into sharp relief the issue of spatial scale and a lack of consideration in transition approaches generally. The study findings reveal a spatial orientation for creating new urban forms of reflexive governance as an innovation process taking place in transition arenas that can trigger new pathways to socio-economic change.
\end{abstract}

Keywords: Reflexive governance; Transition management; Regime transition; Socioeconomic regime; Cities; Social exclusion 


\section{Introduction}

During 5-11 April 2014, the Seventh session of the UN Habitat's World Urban Forum took place in the city of Medellín located in the department of Antioquia in Colombia. Ten thousand participants, representing one hundred and sixty countries convened at the city's exposition centre, Plaza Mayor, for six days of discussions examining the conference's theme "Urban Equity in Development - Cities for Life". The location of World Urban Forum 7 in Medellín was international recognition of system-level transition from most violent city in the world during the 1980's and 90's to a more equitable urban society. This transformation of the systems of an urban society was recognized with the award of 'Innovative City of the Year' for 2013 by Citi and the Wall Street Journal Magazine, in conjunction with the Urban Land Institute (ULI), beating fellow finalists New York City and Tel Aviv.

Social exclusion in Medellín fed by conflict and displacement in Colombia during the 1980's and 1990's was pronounced. Levitas et al. (2006) define social exclusion as occurring when individuals or areas suffer from a combination of linked socio-economic problems such as poor education, unemployment and low incomes, poor infrastructure, high crime environments and the loss of an individual or communities' link to mainstream society. Social exclusion not only affects individuals' quality of life but also the equity and cohesion of city societies as a whole. What is notable in the city from the mid 1990's onward is the emergence of radically new governance arrangements involving communities, city authorities, private firms and other stakeholders in collective experimentation and learning around addressing social exclusion. In this paper we sought to uncover the link between governance as an innovation process in cities and socio-economic regime transition towards a more equitable urban society. To do so, we draw on transition management thinking to consider urban regime transitions evolving in a temporal and incremental manner and in a 
multi-level context. We address in parallel the recent call of Ramos-Mejía et al. (2017) by bringing the poverty alleviation agenda into transitions studies from an urban perspective.

Transition management literature views the regime as forming the 'deep structure' that accounts for the stability of an existing socio-technical system (Geels, 2004). It refers to the semi-coherent set of rules that orient and coordinate the activities of the social groups that reproduce the various elements of socio-technical systems. We sought in this study to expand from a delimited focus on socio-technical regimes to incorporate the notion of urban socioeconomic regimes. This implies a need to distinguish social and economic components of a regime. First, we define the network of actors that carry the regime formed of citizens, city authorities, private firms and other stakeholders. Second, drawing on Rip and Kemp (1998) who view regimes as rules and routines, we frame these actors as being involved in governance arrangements that attempt to coordinate political interactions and policy processes critical to the fulfilment of urban societal needs. Elzen et al. (2012) using the concept of institutions, which fits with sociological and economic institutional theories, consider them as formal and informal arrangements that orient human behaviors and interactions. Specifically, we consider the development of reflexive governance arrangements that are radically new in acknowledging the distributed nature of decision-making and intelligence when developing policies to address social exclusion. This reflexive stance to governance integrates a diversity of perspectives, expectations and strategies in a complex understanding of urban societal change (Voß and Bornemann, 2011). Of interest spatially are reflexive designs for governance at the community micro level as an innovation process (Voß et al. 2007b; Voß et al. 2009) interacting with socio-economic regimes at the city meso level and reflecting national developments at the macro level.

Citizen engagement through the development of radially new arrangements for reflexive governance represents the transition arena, the institutional core of the city's emerging 
transition project. Voß and Bornemann (2011) state that transition management typically assumes transition arenas to be 'depoliticized' in governance terms. Rather than devising sophisticated learning models that correspond to some abstract theory of socio-economic change in cities, the innovation perspective on reflexive governance (see for e.g. (Voß, 2007a), leads us to seek to uncover actual political practices and allowances and constraints of patterns of governing and their dynamics. In doing so we attempt to bend innovation studies literature as a foundation for transition management thinking towards the field of policy analysis for urban socio-economic development by refining the conceptual approach. Essentially, we seek to integrate aspects of reflexive governance and politics in a city context with a basic ontology of complex social systems and their evolutionary dynamics that underlies transition management approaches. Our focus is on learning by doing and experimentation as well as participation of citizens with other key city actors in a new process of mutual learning that seeks to create social inclusion. Reflexive designs for governance that smooth resistance and competing priorities in tacking social exclusion (Voß et al. 2007b; Voß et al. 2009) spatially are positioned at the micro level as an innovation process. Taking place in transition arenas, these radically new governance arrangements are shown to trigger pathways to socio-economic change at the meso regime level in a city.

Inevitably conflict will be present as diverse views and affiliations come to bear constraining mutual learning in new governance arrangements for a more equitable urban society. Rather than being disconnected this political aspect infuses radically new forms of reflexive governance and the capacity to accommodate the plurality of perspectives and related interests concerning socio-economic development needs in a city. Evidence is sought of when and how this starts to change the prevailing regimes through bending them towards the more equitable fulfilment of societal needs in areas such as education, transport infrastructure and employment. The transition project relies on the political dimension to trigger the 
evolutionary selection of transition pathways and goals that ultimately are realized in urban socio-economic transition. Voß and Bornemann (2011) criticize transition management literature for not taking account of potential implications of incumbent policy regimes and the overall policy landscape for policy making within the transition arena. In this sense the landscape macro level and political as well as economic developments are shown to influence the dynamic interplay between socio-economic regime and transition arenas in a city. The transition arena represents the spatial urban location for new reflexive governance arrangements with linkage across the city's communities of interest (micro), socio-economic regime (meso) and national policy (macro) levels. This brings into relief the issue of spatial scale which has received little attention in transition approaches generally (Hodson and Marvin, 2010).

The paper proceeds by developing the literature base for the study. We then introduce the methodology used to conduct the study before presenting the findings. The findings present theoretical implications that are discussed before conclusions are offered.

\section{Literature Review}

Transition studies are focused on linking the dynamics of regime change at the meso level to micro-processes of niche formation whether as a stabilizing or destabilizing factor (Weber and Rohracher, 2012). In transition management literature focused on socio-technical systems, structural transitions are assumed to evolve in a temporal manner and in a multilevel context. Emerging as innovations in socio-technical niches, they shift socio-technical regimes and ultimately affect the broader socio-technical landscape. These systemic changes are often called 'socio-technical transitions', because they involve alterations in the overall configuration of transport, energy, and agri-food systems, which entail technology, policy, markets, consumer practices, infrastructure, cultural meaning and scientific knowledge (Elzen et al., 2004 and Geels, 2004). These elements are reproduced, maintained and transformed by 
actors such as firms and industries, policy makers and politicians, consumers, civil society, engineers and researchers.

Transitions are therefore complex and long-term processes comprising multiple actors. Meadowcroft (2009) asserts that transition management inherently has a messy nature with power struggles and lack of consensus. The management aspect considers approaches to 'managing' the direction and speed of transitions and coordinating and enabling the processes that occur at different micro, meso and macro levels in a more systemic and evolutionary way. Key is the aim to facilitate a more fundamental and long-term reflection on sociotechnical system dynamics in order to overcome the myopic orientation of established policymaking processes. Transition management from this perspective focuses on reflexive governance designs attempting goal-oriented modulation that rejects an attempt to achieve predefined outcomes through planning and control (Kemp and Loorbach, 2006).

In this paper we sought expansion of transition management thinking on governance arrangements from a delimited focus on socio-technical regimes to incorporate the notion of urban socio-economic regimes. Our focus is on its orientation toward system innovation and experimentation as well as participation that serves as a platform to consider radically new forms of reflexive governance design in cities that combines an institutional arrangement (transition arena) with various systemic transition instruments in the transition management process (Kemp and Loorbach, 2006). Hölscher et al. (2017) view the transition arena in a city context as a prominent instrument of transition management. It offers space for what they term pioneers, so-called 'frontrunners', to develop a shared direction and initiatives for transition and to the forming of new coalitions, partnerships and movements. We draw on the thinking of Voß et al. (2006) and Voß, (2007a), defining transition management in cities as an innovation process in incorporating radically new reflexive governance design in shaping structural transitions within complex urban socio-economic systems. New forms of 
governance to tackle social exclusion involving city authorities, private firms and citizens represent spatially speaking transition arenas that can trigger new pathways to urban socioeconomic change. They promote urban partnerships in cities and importantly citizen participation, which are viewed as empowering, democracy enhancing and more effective forms of horizontal, as opposed to more paternalistic, governance structures.

The transformation of a city is not simply a matter of physical changes to urban infrastructure. Addressing a democratic deficit, emerging forms of reflexive governance can give citizens a say in attempts to repair the social and economic fabric of their neighbourhoods and overcome communal suspicions. For the first time they can have an opportunity to work with city authorities, private firms and other relevant stakeholders to define the socio-economic agenda, taking part in political fora and working to implement the agenda. This creates a very different relationship between the planning bureaucracy and the residents. The reflexive nature of radically new governance arrangements represents enfranchisement of communities oblivious to government or deeply resentful of it. Inevitably there will be political tensions and competing priorities but what is of interest is how radically new governance arrangements in a city facilitate mutual learning among diverse interests in the pursuit of social inclusion.

New forms of governance in a city represent the transition arena at a micro level, the institutional core of the city's emerging transition project. Voß and Bornemann (2011) indicate that reflexive governance arrangements at the local level encourage collective experimentation and learning in the development of socio-economic initiatives. Governance arrangements influence regime change if expectations among diverse urban interest groups became more precise and more broadly accepted, and if the alignment of various learning processes result in a stable configuration ('dominant design'), and if actor networks become larger (especially the participation of powerful actors to convey legitimacy and resources to 
develop socio-economic initiatives). Existing socio-economic regimes at a meso level may be characterized by lock-in that excludes communities from equitable education, transport infrastructure and employment opportunities. These incumbent regimes may also the location for experimentation with new governance arrangements and creation of new levels of expectations from citizens. Referring to Voß and Bornemann (2011), this can enable participating actors to explain diverging understandings and ideas pertaining to socioeconomic development needs and reflect their particular views in relation to the diversity of others. While not reflecting a unified strategy for dealing with urban socio-economic change, the plurality of perspectives and related interests and the need to be accommodated is brought to the surface.

Kemp and Loorbach (2006) point to the significance of a political context in considerations of transition management from a governance perspective. However, the articulation of governance designs largely do not take account of the contested character of transitions and power-related strategic activities. New governance arrangements in a city represent, spatially speaking, the politicized urban crucibles in a wider city context for mixing together diverse actors with divergent socio-economic priorities. Politics is central because the existing socioeconomic regime at the city-level is stabilized by political lock-in mechanisms and because new initiatives to tackle social exclusion may have a miss-match with the existing regime dimension. Backlashes and dissenting voices and elites in a city threatened by socioeconomic change mean that the new forms of governance as transition arenas need to expand to take account of these challenges from powerful political constituencies in the city. Reflexivity in governance arrangements can 'soften' the emphasis on consensus as a source of legitimacy by acknowledging plurality and political struggle between discursive urban social spheres as a basis of transitions (see for e.g. Grin, 2006; Hendriks and Grin, 2007). 
Hodson and Marvin (2010) in respect of cities state that the production of a vision is an important participatory process used to engage, inspire and mobilize social actors with divergent views and interests but involves negotiation and struggle. They see the vision as a necessary but not sufficient condition of urban decision, with innovative forms of reflexive urban governance design crucial to achieving the coordination of diverse actors to act on the vision. While not fixed and liable to change over time the vision can gain commitments to 'participate' in new governance arrangements, orientating the actions of participants and persuading constituencies in the city of the desirability of transition. We view a city vision as important to smoothing inevitable conflicts through arrangements for reflexive governance that allow participants to adjust their perspectives and definitions of the issues around social exclusion accordingly (Kemp and Loorbach, 2006). A city vision is therefore only as good as the governance arrangements through which the vision achieves or fails to achieve 'acceptance' amongst actors and translation into what Hodson and Marvin (2010) term 'materiality' 'on the ground' such as, for example education, transport infrastructure and employment initiatives. Of interest is how the political dimension of the vision infuses into reflexive government arrangements and ultimately how this influences socio-economic transition pathways translating the vision into operational means.

Of particular interest is evidence in cities of Smith and Raven's (2012) ideas on protective spaces, empowerment and the transformation of selection environments. Specifically, of interest is evidence of transition arenas and governance arrangements that may be seen to be forms of what they term 'fit and conform' or 'stretch and transform' empowerment. What is interesting in a city context is how political process integrates with the transition management cycle through for example vision setting activities to inform socio-economic priorities (see Guy and Marvin, 1999; Guy et al. 2011 on role of vision in sustainable cities and competing urban futures). Weber and Rohracher (2012: 1039) state in this regard, "With a future 
orientation, transition management focuses on strategies to create new dynamics of change processes through learning processes in niches, alignment of actors, orientation and coherence through vision building processes". New governance arrangements at a community level interacting with a city's socio-economic regime may then offer what Voß and Bornemann (2011) refer to as procedural provisions that can work as safeguards against domination of vulnerable communities and capture of learning processes by powerful actors in the city. It may be that powerful public or private sector actors in cities can provide legitimacy and resource for new forms of governance and for related policies that allows communities to, for example, take responsibility for allocation of municipal budget in their neighbourhoods (Maclean, 2014). Hodson and Marvin (2010) highlight the importance of such intermediaries to constitute space outside of the obduracy of both existing urban governance arrangements and existing socio-economic regimes; bringing together competing economic priorities and social interests. An important part of this study will be to assess the role of intermediaries in mediating different priorities in new governance arrangements and helping to develop the reflexive capacity to influence urban socio-economic regime.

The juxtaposition of national (macro), city (meso) and community (micro) level interactions and their impact on socio-economic regime transition brings into sharp relief the issue of spatial scale and a lack of consideration in transition approaches generally (Hodson and Marvin, 2010). The consequence is a lack of clarity about the spaces and places where transitions take place. Within the national view of transitions the role for sub-national scales such as cities and localities is not clear. Specifically, transition management thinking has said little about cities and the context of urban transitions. Central to this for the study at hand is the relative positioning of a city in terms of position in urban hierarchies and governance capacity within national and localized transitions. Sutherland et al. (2015), more generally, acknowledge the limited conceptualization of landscape developments in transition 
management literature. Geels and Shot (2010) show that timing, duration and magnitude of landscape level developments are critical to patterns of transition pathways. The embedding of innovative new reflexive governance arrangements and their impact on the development of transition pathways to more inclusive socio-economic development in a city will inevitably be impacted by national developments. Voß and Bornemann (2011) and Meadowcroft (2005) indicate that reflexive governance designs based on experimentation and learning will be susceptible to broader political contexts. Essentially, there will be multiple scales of governance action with differing sets of power relations in a city as a location for urban socio-economic transition. It therefore seems pertinent for this study to consider the larger national political and economic system in order to assess impact on the socio-economic interactions between transition arenas and regimes in a city.

In this paper we sought to uncover and analyse historical processes of system innovation in Medellín, emerging from complex linkage dynamics between socio-economic regime, transition arenas and landscape. Smith et al. (2007) indicates that linking rarely means that socio-economic practices in Medellín in transition arenas are simply adopted by a regime (or vice versa). Some form of translation needs to be accounted for oriented around a focus on learning by doing and experimentation as well as citizen participation in transition arenas with city authorities, private firms and other interested stakeholders. Building on the work of Voß and Bornemann (2011) we seek to identify evidence of reflexive governance in an innovation process within transition arenas, specifically the:

1) identification of transition arenas spatially located at a community level in Medellín bringing together actors with diverse and conflicting interests and facilitating radically new forms of interaction and learning towards tackling social exclusion.

2) building of social networks and the enrolment of actors including citizens, city authorities, 
private firms and other interested stakeholders coalescing around their capacity to contribute to addressing social exclusion.

3) articulation (and adjustment) of shared socio-economic expectations among actors with diverse interests focused on social exclusion and attracting attention and resources from intermediary actors.

4) facilitation of processes of mutual adaptation on various socio-economic dimensions reflective of adequate ways to work with conflict and power in the process of experimentation and learning.

The study of these processes in transition arenas and their role in enacting systemic socioeconomic change at the city level is illustrated through an empirical study of Medellín, with the methods adopted discussed below.

\section{Methods and background to the case}

Medellín is located in the Aburrá Valley, one of the most northerly of the Andes Mountains in South America, and is the second-largest city in Colombia with a population of 2.2 million people. Colombia is an emerging Latin American economy with an average economic growth rate of $4.1 \%$ in the past 4 years and a total GDP of $\$ 369.6$ billion in 2012 . Medellín while traditionally seen as the industrial center of Colombia has exhibited some of the highest levels of social inequality and exclusion among its citizens. What Maclean (2014) terms 'the Medellín Miracle' is attributed to extensive social investment to address social exclusion that transformed some of the poorest areas of the city. Socio-economic change relied on a shift in national policy and attitudes of political and business actors at a city level, which created the space for new governance platforms for citizens to shape socio-economic policies. In this study we sought to uncover the link between governance as an innovation process and socioeconomic regime transition in Medellín towards a more equitable urban society. The research 
was undertaken utilizing a combination of document review, in-depth interviews with elite informants in Medellín's. These data sources were assessed to identify key events and factors from the 1950s through to the late 2000's that define Medellín's socio-economic regime transition; identifying apparent trajectories of incremental transition in the time periods. We sought to identify forms of translation in Medellín's transition arena-regime connections by considering radically new governance arrangements concerning the areas identified above. Documents included internal and external sources such as archival records, policy reports and scripts, press releases, annual reports and presentations. External sources included media and professional articles identified in print form and through the Internet. We located around 50 articles in total. Fifteen in-depth interviews were conducted in Medellín with what Yin (2003) terms 'elite informants' involved in education and employment policy, urban development, utility provision, transportation infrastructure and the University sector among others. Each interview lasted up to one and a half hours and was conducted in the native Spanish by one of the researchers. Data gathered was analysed using qualitative data analysis techniques to categorize and code themes. Findings presented are illustrative in providing narratives of governance development and Medellín's socio-economic regime transition, rather than a comprehensive assessment of the factors underpinning the transition processes over time.

\section{Findings}

In this section we analyse from the study findings evidence of the link between governance as an innovation process and socio-economic regime transition in Medellín. Analysis identifies three regimes covering a historical time period: 1) Stagnation regime (Medellín: 1950s1990s); 2) Genesis regime (Medellín: 1990s-2000s); 3) Rejuvenation regime (Medellín: 2000s).

\subsection{Stagnation regime - 1950s-1990s}

Medellín has a tendency to be viewed today as having overcome a period that lacked 
governance arrangements. Painter (2009) views the complex interactions between the state, communities, paramilitaries, guerrillas as a process of social and economic coordination, management and steering. A distinct form of governance structure was inadvertently established in Medellín through the complex interactions of the wealthy and poor, the formal and informal (Bahl, 2011) - interactions framed by ill-functioning city institutions with conflicting economic, political and social objectives. Bahl notes that the rise of this governance structure evident in Medellín up to the 1990s primarily can be related back to economic stagnation in the 1950s at the national level in Colombia with mass migration following La Violencia (The Violence). Colombia has a history of conflicts involving actors from right and left, contributing to the violence in Medellín over these years. La Violencia involved conflict between Liberal and Conservative parties and between Marxist guerrilla, paramilitary and state forces. Medellín's specific structures, dynamics and contingencies were key to the conflict in the city drawing from this national level context.

Medellín's industrial development whilst enabling the city to become the country's industrial centre prioritised the needs of business and political elites. Bahl (2011) notes that a clientelist style of politics engendered a vertical governance structure alongside a paternalist political culture blurring the lines between formal and informal power. This led to high levels of inequality and social exclusion in Medellín's poorest neighborhoods, even measured by Colombian national standards. The social geography of the city itself exacerbated the inequality and social exclusion to be found there. The over-crowded, steep areas of the valley had poor access and infrastructure and migrants to the city in the 1950s, including those displaced by rural violence, had no other option but to take up residence in those areas. A cyclical pattern emerged in which violence and clientelism exacerbated the weakness of city public institutions, and in turn, permitted further violence (Maclean, 2014). Upheaval over the city's governance deteriorated the urban fabric and destabilized the livelihoods of 
vulnerable communities creating a lack of trust in political structures and constraining socioeconomic progress. Even once migration reduced significantly in the 1980s, neither governance nor social integration improved.

Bahl (2011) notes a tradition of patronage in elite culture in Medellín, with business owners priding themselves in having good conditions, housing and schools for their workers and their families - values that are embedded in affiliations with Catholicism. This patronage affirmed power relations rather than extending social inclusion and addressing inequity. Exclusion and inequality underpinned the rise to power of informal political actors in Medellín, although these are characteristics are by no means unique to this city being evident in many cities around the world. Medellín's ruling elite prided themselves in having created the country’s foremost industrial city. Although economically powerful families are characterised by a commitment to investing in their workers, it can be argued that this paternalist approach exacerbates social exclusion (Hylton, 2007). As social rights, such as housing and education, were dependent on employment, the effects of recession and de-industrialisation associated with the economic crisis of the 1980s, and felt particularly harshly in Medellín. The unemployment rate in Medellín varied from 14\%-17\% from 1982 to 1988, but much more significant was the size of the informal economy, which was estimated to provide more than $50 \%$ of employment throughout the 1980s (Betancur, 2007). Migration from rural areas continued apace during the 1980s and 1990s, despite the growing rates of poverty and violence, and the poorer areas to the North and North East of the city were dominated by informality - from petty commerce to sex work and involvement in criminal gangs and cartels. The sense of exclusion and the material realities of survival in these areas were central factors in how violence gained such traction in Medellín (Maclean, 2014).

To sum up the history of Medellín from the 1950s onwards has arguably been conducive to creating conditions for social exclusion and inequality with the rise to power of informal 
political actors in the city and governance arrangements protecting narrow social and economic interests. However, it could be argued that these governance arrangements and the desperation of many citizens at all levels of the city created a desire to change both to governance structures and the material circumstances of the poorest. Indeed, while in a downward spiral the seeds of socio-economic regime transition were planted in the late 1980s with the emergence in the city of new and radical forms of citizen participation and local democracy as a response to violence and disenfranchisement. The informal political actors and private firm interests in response to out of control violence and instability began to respond in tandem by promoting bold new governance reforms to foster tolerance and create a 'citizen culture' that could be embedded socially and economically within the fabric of the city. We develop this further by considering how these seeds of transition from the Stagnation regime grew to become a Genesis regime during the 1990s in the next section below.

\subsection{Genesis regime - 1990s-2000s}

The conflict and political destabilization from the 1950s through to the 1990s had the effect of destabilizing Medellín. The city gained a homicide figure in the 90's that was twice the national rate. The problem of Medellín's violence was to do with the processes of structure and agency that allowed violence to become part of the fabric of the city and the way in which power was accumulated and politics conducted (Bahl, 2011). There was a concurrent lack of adequate investment in public spaces, schools and transportation infrastructure in these communities. For example, it would typically take two hours to reach the commercial center of the city from Medellín's poorer hillside neighborhoods. Education and learning in the city faced significant constraints from primary through to tertiary levels, pronounced in the deprived communities. The University of Antioquia was subjected to regular protests in its vicinity, with security and wire fencing hardly conducive to promoting learning and 
inclusivity of opportunity. This period while a dark time in Medellín's history sowed the seeds of social and economic transition germinating from the mid-1990s onwards.

The peak in the murder rate during the early 1990s corresponded to long-term political processes, socio-economic dynamics and immediate contingencies converging, with new spaces opened up in the social and political fabric of the city that allowed critical, progressive actors to make changes with dramatic effects (Bahl, 2011). What appears to have happened in Medellín at this time is that citizens found new informal governance spaces in the midst of a crisis to pursue socio-economic transition and interrupt the process and cycles of violence. There was a recognition that, in order to survive in a global economy and attract foreign investment, the city had to change. This was encouraged by landscape developments at the national level, with the mid and late 1990's seeing decommissioning under a national Colombian government initiative of paramilitary groups that held sway in poor neighborhoods. Alongside this, the late 1990's saw the beginning of economic recovery in Colombia. Major economic policy decisions by the Central Bank and supported by the International Monetary Fund, focused on reducing inflation and on reforms to the tax and pension systems to make Colombia more stable and competitive internationally. These national developments coincided with a political decentralization process that had a significant impact on Colombian cities. Until 1988, power had been concentrated at the national level, with presidents appointing governors and mayors who had limited powers. Bahl (2011) notes that decentralization began with the first popular election of mayors in 1988 and culminated in the 1991 promulgation of a new constitution that greatly increased the powers and responsibilities of municipal governments. This process while not immediately beneficial to Medellín did open up the political space for the progressive tenure and social urbanism of Sergio Fajardo during the 2000s.

An important element noted by MacLean (2014) was the Consejeria Presidencial 
(Presidential Programme) for Medellín initiated in 1990. Implemented as a national-level programme supported by a significant national budget it was tasked with developing solutions for the city. Such initiatives at the macro level opened the door in the early 1990s at a micro level in the city for NGOs, universities and other non-traditional political actors to collaborate together in setting a new governance agenda for Medellín that was arguably key to transition from the Stagnation to a Genesis regime during the 1990s. With legitimacy and financial backing from national Government these stakeholders were able to transcend the formal political actors implicated in the political dynamics underpinning social exclusion in the city (Maclean, 2014). Newly defined socio-economic priorities from this political distribution of power in Medellín and new political actors created the protected spaces in which radical new thinking on governance arrangements could be experimented with based on coalitions with shared interests in addressing social exclusion. This produced initiatives such as PRIMED (Integral Program for Subnormal District Improvement in Medellín), which aimed to better the life quality of the citizens of deprived neighborhoods and ambitiously unify the city (Bahl, 2011). At a meso level the Strategic Plan for Medellín 1995-1998 presented a radically new vision for the city based around key considerations such as a need for: infrastructure projects; conspicuous investment in poorer areas; development of public space; participation. The support of international policy makers, development organizations and policy specialists provided legitimacy for radically new forms of governance and, crucially, financial support. These developments drew in part from a commitment from among elite actors in Medellín that it was necessary for socio-economic change to happen. This commitment was based upon recognition of what was viewed as an historical 'social debt' owed to deprived and marginalized areas of the city.

NGOs, universities and other non-traditional political actors encouraged by national level initiatives formed what Maclean (2014) terms a 'reflexive middle class'. They actively 
coalesced in Medellín at a micro level integrating actors with diverse and conflicting interests and facilitating radically new forms of interaction and learning towards tackling social exclusion. Foros Comunales (community fora) developed 'alternatives for Medellín', involving political, community and business leaders as well as international actors, including the United Nations Development Programme (UNDP) (Maclean, 2014). Compromiso Ciudadano (citizen engagement), formed in the 1990s, consisted of prominent NGOs, trade unions, business leaders, neighborhood associations and voices from the political left, center and right. These initiatives represented what Hölscher et al. (2017) terms urban transition arenas that offered space for pioneers to develop a shared direction and initiatives for socioeconomic regime transition and to the forming of new coalitions, partnerships and movements. Maclean notes that established political elites were often opposed to the challenge presented to their hold on political power and in response remained outside of these transition arenas. Notwithstanding, in governance terms the principle of participation was informally established at a micro level among actors in the city traditionally outside of the political and economic elite and with the backing of formal macro and meso level initiatives such as the Presidential Programme and the Strategic Plan for Medellín. This aligns with Wood and Gough's (2006) work on institutional landscapes for social inclusion with formal and informal institutions overcoming problems of legitimacy and moving from control by political and business elites to create greater levels of social inclusion. Formal initiatives such as the national level Presidential Programme and city level Strategic Plan for Medellín along with the building in governance terms of citizens' capacity to participate created the conditions for these informal transition arenas to become protected spaces to pioneer initiatives to tackle social exclusion. Overarching this was a realization among many different interest groups including political and business elites in the city of the need for change to counter the process and cycles of violence. Interestingly, the Compromiso Ciudadano directly 
countered opposition by entering formally into the political arena in the late 1990s to challenge the political establishment.

The formal redistribution of political power in Medellín opened up transition arenas as protected spaces for previously marginalized communities to have the confidence to challenge established political power. This changed the dynamic between city policy makers and community organisations with city political and business establishment actors collaborating with citizens to shape the socio-economic agenda. An example provided by Maclean (2014) was Corporación Convivamos formed in 1990 in the North-East zone of the city by left-leaning citizens that had been previously active in their communities. It aimed to promote development via education, community support and participatory governance. Reflexive forms of governance created opportunities for community groups such as to challenge socio-economic policies and pioneer new policies that addressed poverty and social exclusion in their neighbourhoods. Maclean (2014) indicates that power was delegated to Corporación Convivamos, and other similar community organisations, giving them a place at Medellín's political table. These transition arenas sought to give citizens 'co-responsibility' to repair the social and economic fabric of their neighbourhoods and overcome communal suspicions and violence. For the first time they had the power to define and take responsibility for the socio-economic agenda. However, a significant challenge was suspicion and a lack of experience by people in traditionally marginalized communities in engaging with formal governance processes. The democratic deficit built up over time and lack of formal governance structure presented a challenge to governance arrangements. To overcome this attempts were made to raise awareness of reflexive participatory processes from the early 1990s, with a focus on training and educating community groups so that they could get involved in initiatives such as the Participatory Budget and have a say (Maclean, 2014). 
The Participatory Budget initiative introduced under the tenure of Mayor Juan Gómez Martínez Perez in 1998 was more than an economic initiative. It was a political initiative designed to leverage reflexive governance experiments by empowering citizens to determine their own priorities and increase transparency of how funds are spent. The specific ways to implement the participatory budget and the kinds of programmes that it supports was contentious. Nevertheless, it overturned decades of development in which investment was steered by political and economic elites at the city level who did not grasp the socioeconomic priorities of people in the comunas. Taking advantage of the pioneering activities through transition arenas and work on new infrastructure such as the Metro development, which finally started construction in the late 1980s with two lines and about thirty stations opened in 1995, the department of ubanismo social (social civil planning) at the Medellín Academy during the late 1990s sought to consolidate radically new forms of interaction and learning towards tackling social exclusion in Medellín. The focus was on providing people with a say on ways to re-conquer spaces lost to violence; scoping out and experimenting with new ideas on better transport connectivity for neighborhoods, opening up public spaces, building new schools and centres of learning, creating legitimate employment opportunities. These initiatives in Medellín challenged the very nature of established governance in the city which tended to be defined by an individualist, vertical structure with few checks and balances (Maclean, 2014).

Maclean notes that the more horizontal structure necessitated by transition arenas presented a significant challenge to the image of the paternalist, vertical leadership in Medellín which had been a factor in allowing violent actors to gain power during the 1980s and 1990s. It implies movement from hierarchical top-down exercises of power to a more horizontal and networked systems that relied on the interaction of interdependent actors in transition arenas and a high degree of trust. Transition arenas with their formalized national and increasingly 
city-level political support were central to this as protected spaces where citizens could develop radically new governance approaches to face insecurity and uncertainty. They drew on a pool of defiance and resilience in Medellín's poorest neighborhoods and a desire to begin looking outward and forward with hope for a better future. However, trust could not be assumed with the challenge not just finding solutions for pressing socio-economic problems but also finding a way to institutionalize new participatory platforms emerging during the 1990s to create shared socio-economic expectations among stakeholders with diverse interests and goals. This challenge formed an important element of transition from the Genesis regime to the Rejuvenation regime taken up with gusto in the 2000's under the Mayoral tenure of Sergio Fajardo.

\subsection{Rejuvenation regime - 2000s}

By early 2000 at the landscape level significant economic development in Colombia built on the shoots of recovery during the late 1990's. The election of Álvaro Uribe as Colombian President on August 7, 2002, engendered a growing sense of confidence in the national economy, particularly within the business sector; GDP growth in 2003 was among the highest in Latin America, at over 4\%. By 2007, GDP grew over 8\% and overall during the 2000's Colombia experienced a historic economic boom to become one of the world's fastest growing economies. Primarily driven by the export sector, it enjoyed the benefit of a more competitive exchange rate as well as strong prices for petroleum, Colombia's leading export product.

Building on these landscape developments the election of Sergio Fajardo as mayor of Medellín in 2003, serving to 2007, was a significant development in the recent history of the city. Fajardo formalized the radically new forms of reflexive governance experimented with and developed during the 1990s discussed under the Genesis Regime. Indeed he was a 
leading figure during the 1990s in their development through his role in Compromiso Ciudadano. His desire to 'give the best to the poorest' led to initial clashes with the political elites in the city council, which had a reputation as a bastion of patronage politics and corruption. Fajardo's landslide victory, his popularity at the polls and independent political background allowed him to overcome this resistance and to bring together citizens from deprived neighbourhoods, academic and business institutions. The most important aspect of Fajardo's early term in office was to provide political commitment to formalizing the new forms of reflexive governance emerging at the micro level during the 1990s under the banner of serving all of the city. He institutionalized governance arrangements and oriented them toward the needs of the poorest neighbourhoods. These new institutionalized transition arenas were termed by Fajardo's administration 'civic pacts'. In these pacts central priorities were defined and localized partnerships formed supported by specific reflexive methodologies to deploy to tackle social inequalities in deprived and marginalized neighbourhoods (Bahl, 2011). We view these pacts as having the values and principles that Ramos-Mejía et al. (2017) state underlie transformation processes; according to which pathways to greater levels of social inclusion in Medellín are promoted to various extents by diverse actors and networks. Concurring with Smith et al. (2014), the pacts as more formalized transition arenas constituted innovation spaces for bottom-up forms of socially inclusive futures for the city.

Social objectives for the pacts focused on local community participation, organization and leadership. These were aligned with institutional objectives focused on coordinated action among city authorities, private firms, community-based representatives and other relevant external stakeholders. Representatives of the mayor's office would meet with neighbourhood groups to explain a planned project, collect feedback and generate local support. 'Workshops for Imagining Projects' engaged citizens to envision designs and what was needed socially and economically. After the neighbourhoods' feedback had been incorporated into the 
designs for a infrastructure project such as a new library or school, local leaders and municipal officials (often Fajardo himself) would sign an agreement that committed the city to faithfully execute the project and for citizens in the neighbourhood to contribute directly. Fajardo's office would then distribute copies of the pact throughout the neighborhood and publicize its signing citywide on local media before work would begin. Citizens were involved in implementation through employment and through taking symbolic ownership of completed projects in the organization of community events. Civic pacts ensured a sense of ownership and co-responsibility among the citizens in deprived neighbourhoods and strengthened the sustainability of the projects and programs. The creation of transparency and trust with co-responsibility and open communication was seen as being particularly difficult to achieve between elites with narrow interest sets and communities wrecked by years of violence and distrust in local political and economic structures. Creating interdependence between these groups was seen as a major potential challenge. To overcome this Fajardo viewed the pacts as a pedagogical exercise in which citizens long abandoned by city governance structures could contribute and assess the importance of their contribution and involvement in governance. Major projects included the Parque Biblioteca España library, a source of free classes and Internet access for all ages, and a place for the community to gather. Other examples include the León de Greiff library in La Ladera, a trio of buildings with well-connected cantilevered pods on slate pedestals, splayed like a fan across the brow of a hill is linked to a park next door and the views are spectacular through panoramic windows. These library-parks were anchored into local life through community and cultural activities, including reading and computer literacy programmes.

The reflexive nature of civic pacts as a radically new and formalized form of governance at the micro level represents a historic enfranchisement of communities that had been either oblivious to city government or deeply resentful of it. A new of idea of citizenship formed 
through these transition arenas with people challenged to take individual and collective responsibility for the initiatives to address social exclusion working collaboratively with city authorities, private firms and other relevant stakeholders. Fajardo complemented this by building on his predecessor Mayor Perez's introduction of Participatory Budgeting first implemented in 1998 (Maclean, 2014) . He enlisted citizen support for his agenda by opening the planning and budgeting process to public participation. The administration allowed citizens from deprived neighborhoods to decide how to spend portions of the municipal budget to develop for example new "quality schools." The city authorities collaborated with these schools to develop a "quality pact" which would be signed by Fajardo, the school's administrators, teachers, students and parents from the deprived neighborhood. Fajardo promised to renovate and resupply the school, while teachers and students pledged to do their best, and parents committed to providing local oversight. Within four years during the 2000s, the percentage of public high school students performing at below-average levels on the national standardized graduation test dropped to $11.6 \%$ from $65 \%$ (Bahl, 2011). In the same period, the proportion testing above average rose to $36.9 \%$ from $6.4 \%$. New schools and quality pacts brought pride back to previously neglected community and a sense of empowerment through co-responsibility for their development. For example, people were now proud to say their children were being sent to the city's 'best' schools and that they had a 'positive future'.

Alongside educational developments the role of new initiatives to encourage participation in the formal city economy was important. Cedezos (Centros de Desarrollo Empresarial Zonal) were formed as a network of publicly funded business support centers located in the poorest areas, offering support in developing business by providing free-of-charge business support services and technical advice. These 'entrepreneurial development centers' encouraged new business ventures and innovation offering new opportunities. Cedezos allowed people to get 
cheap credit loans in order to startup businesses such as a café or a shop - microloans at cheap interest rates to establish microenterprises. This helped create more equality of opportunity and overcome barriers to entry to business start-up for entrepreneurs with good ideas, but lacking capital, skills and connections trade. Integrating transport infrastructure with Cedezos through initiatives such as Metrocable, connected them with the commercial heart of the city center and breaks down Medellín's north-south socio-economic divide. A new bridge connected the previously warring neighborhoods, diminishing continuing remnants of inter-communal suspicion and violence.

New governance processes and business start-up initiatives essentially sought to reconstitute the social and economic fabric of the poorest areas of the city decimated by decades of violence. Citizens' participation attempted to build new norms of democratic behavior. There were inevitably also tensions with Maclean (2014) pointing to different motivations and ideas that underpinned the central notions of social equity and solidarity. Different interpretations were evident around education, participation, solidarity economy, where agendas coincided but the ultimate aims differed. We view two integrated areas as important to attempts at reconciling these differences in terms of new governance arrangements in the transition arenas: 1) the city vision; 2) the attention and resources from intermediary actors.

A new city vision worked out with input from citizens from across the city was defined by the banner "Medellín, Commitment of all the Citizens", sought: 'to fight poverty, develop transparency and zero corruption, and create urban physical interventions to connect poor areas with the city'. Education, Entrepreneurship and Cluster Economy formed three core policy pillars. A fundamental theme of the vision has been termed "Social Urbanism". The thrust of this was a focus on social equity through urban policies and giving priority to the areas of the city with significant socio-economic issues. Fajardo was careful to term social urbanism an experiment and not a model but is has come to be considered a critical element 
within the city vision for socio-economic change. The city vision formed the framework for policies and new governance arrangements focused on the poorest areas of Medellín. Participatory forms of budgeting as discussed with the civic pacts were key radically new governance processes. The socio-spatial scope of the vision while restricted to a few urban areas did target areas experiencing significant social exclusion and poverty. Perhaps most importantly in terms of socio-economic regime transition, the city vision and its underpinning social urbanism ideals represented for citizens a break from the past and for the first time a chance to be directly involved in decisions affecting schooling of children, infrastructure and employment opportunities.

The implementation of the city vision required the attention and resources from intermediary actors representing the structures of elite control. Most prominent is the public utility company Empresas Publicas de Medellín (EPM), with financial backing coming directly from $7 \%$ of its regular dividends given each year to the city, equivalent to $30 \%$ of its annual revenues (Maclean, 2014). Some 70\% of EPM's profits (around $\$ 450$ million a year) directly supported the development of new schools and learning centers, public plazas, the metro and other integral transport infrastructure. EPM's structure operating as a private firm and paying taxes, while also being owned by the City of Medellín who pay for its utility services, has allowed it to play a strong role in the city's socio-economic rejuvenation, without compromising its commercial position. It has had a role specifically in supporting the Participatory Budget initiative. Engineering and construction firms and architecture practices were also crucial to enabling high-status signature architectural initiatives with new integrated transport infrastructure. Colombia's most renowned architect Rogelio Salmona designed public buildings for Medellín's most deprived neighborhoods and other leading architecture and engineering firms got involved in projects that in their design were focused on promoting new education and learning opportunities. 'Imagination workshops' were held 
so that the architects could partner with communities to identify the unique socio-economic development needs of the territory where the project was to be developed. Then, construction and engineering firms employed $80 \%$ of the community in building educational facilities and associated infrastructure. Architecturally acclaimed educational facilities include libraries, literacy projects, art centers with accompanying new public spaces located in neighborhoods that were once blighted by violence.

When Fajardo left office at the end of 2007, Medellín had undergone a socio-economic transformation. The city, on the brink of collapse just four years earlier, was now touted by the Inter-American Development Bank as an example of effective municipal government. It should be noted there were criticisms, such as: inaccessibility of library-parks; limited economic impact of Cedezos; limited transport mobility. However, these are criticisms that need to be located in the overall transition from the Stagnation regime to the Rejuvenation regime presented in the findings. The overarching achievement of Fajardo and his brand of social urbanism building on the significant progress made during the 1990s was recovering the trust and buy-in to radically new institutionalized governance structures by citizens, private firms, city authorities and other relevant stakeholders.

\section{Discussion}

A major proportion of the world's population will be located in cities by 2030 . With cities globally facing challenges due to the social exclusion of significant proportions of their populace, new thinking is needed on ways to correlate the competing socio-economic goals of various actors. This study draws on transition management literature to uncover the link between governance as an innovation process and socio-economic regime transition in Medellín towards a more equitable urban society. Ramos-Mejía et al. (2017) note that despite increasing attention on the politics of socio-technical transformations in transitions literature more focus is needed on the questions: which transformation?; for whom?; and by whom? 
Answers to these questions can help us understand the kind of sustainability these transformations bring about. Focusing on urban socio-economic transformation our study findings reveal how reflexive designs for governance smoothed resistance and competing priorities in tacking social exclusion (Voß et al. 2007b; Voß et al. 2009). Spatially, the building of social networks and adjustment of shared socio-economic expectations among diverse actors in a city is positioned in transition arenas as an innovation process (e.g. Voß, 2007a). Radically new governance arrangements at a community level trigger new pathways to socio-economic change at the city level while reflecting developments at the national level. We detail clearly the political tensions and competing priorities but also how new governance arrangements in Medellín facilitate mutual learning among diverse interests in the pursuit of greater social inclusion. The contribution is defined more specifically below.

\subsection{Transition arenas and their role in urban socio-economic regime transition}

Governance during the stagnation regime (1950s-1990s) was framed by ill-functioning city institutions that facilitated social exclusion. Decentralization at the national level during the 1990s increased powers and responsibilities of the Medellín city authorities and created newly defined socio-economic priorities. National security and economic developments in Colombia along with efforts to devolve power downwards during the 1990's, provided a broader context for the beginnings of a participatory approach with new thinking to overcome communal suspicions and violence. The findings revel that new political actors exploited this with new thinking on the very notion of governance, experimenting with participatory coalitions involving citizens, city authorities, private firms and other stakeholders. Kemp et al. (2007) indicate that the transition arena spans various levels and sectors of governance. However, Voß and Bornemann (2011) criticize the political implications of transition management literature for focusing on the transition arena at the niche level over meso and macro levels of politics. We position the transition arena as the spatial urban location for new 
reflexive governance arrangements with linkage across a city's communities of interest (micro), socio-economic regime (meso) and national policy (macro) levels. Going beyond much of the transition management literature, the findings reveal how the transition arenas and their evolution during the 1990s and 2000s significantly influenced Medellín's socioeconomic policy. They exerted a transformative power on existing socio-economic regimes while being influenced by national level developments.

A tangible example is the Foros Comunales (community fora) set up to discuss alternative futures for the city. One of the core precepts of governance is that a broad engagement of actors can result in a more effective management of urban affairs - that intended outcomes can be achieved efficiently and responsibly (Hajer and Wagenaar, 2003; Swyngedouw, 2005). These transition arenas introduced a radically new form of reflexive governance, placing themselves within complex socio-economic systems and acknowledging the inherent complexities and uncertainties of these systems. Noting the work of Voß and Bornemann (2011), the study findings on transition arenas in Medellín during the 1990s consider the political conditions of governance. This goes beyond transition management thinking that Voß and Bornemann criticize for assuming such spaces are shielded against the influence of politics. The strengthening of community agency and participatory democracy was given legitimacy to enact socio-economic change. New modes of engagement between actors supported and legitimized by the Presidential Programme and the Strategic Plan for the city challenged the hierarchical top-down exercises of power with a more horizontal and networked systems that relied on the interaction of interdependent actors in transition arenas. However, given the often divergent goals of the various actors the process of transition was also liable to a struggle of competing ideas and desires. Referring to Voß and Bornemann (2011), social learning in the transition arenas required acknowledgement of conflict, power and actors seeking to dominate to further their own socio-economic interests. In this regard 
we link transition arenas to Smith and Raven's (2012) ideas on protective spaces, empowerment and the transformation of selection environments.

Specifically, they may be seen to be a form of fit and conform empowerment. Corporación Convivamos as a transition arena at the community level represents a 'temporary' site that was conditional upon improvements in radically new governance arrangements being nurtured in that space. It 'fitted and conformed' with a relatively unchanged socio-economic context in Medellín. Corporación Convivamos existed within an institutional environment that was still deficient in terms of supporting reflexive governance practices at a community level. People in these communities and other actors were participatory actors without any formalized city vision or institutionalized political support. This strengthened the position of actors resistant to its pioneering approach to governance in the city. The sustainability of the new governance arrangements reduced through the pressure to fit and conform to a still immature institutional political environment in Medellín. Arguably, Corporación Convivamos through its radically new governance arrangements was 'empowered' in that it contributed to a shift in thinking among political and business elites towards support for Fajardo's civic pacts and associated vision for the city in transitioning the Genesis regime to the Rejuvenation regime during the 2000 s.

At the dawn of the new millennium while renewed optimism was evident given the changes during the 1990s Medellín still faced high levels of poverty and a lack of institutional support for participatory processes in the city. At the national level the election of Alvaro Uribe as President of Colombia in 2002 created a new push to eradicate violence. This coincided in Medellín with the election of Sergio Fajardo as Mayor of the city serving from 2004-2007. Fajardo was able to bridge the gap between the business and political elites and the vulnerable communities on the hillsides (Bahl, 2011). He was directly involved with the 
emerging participatory forms of governance during the 1990s and taking office determined to tackle head on social exclusion in poor neighbourhoods. He viewed the notion of reflexive forms of governance involving diverse socio-economic interests in the city not as a threat but rather as a means to legitimize a new democratic model for the city. This can be seen as a means to ensure the maturation of local citizenship. Significantly, transition arenas gained institutional support through the forming of civic pacts under Mayor Fajardo.

The transition management literature while advocating the institutionalization of such governance practices has yet to effectively interrogate the processes of institutionalization (Smith and Stirling, 2010). Authors such as Kemp et al. (2007) and Voß and Bornemann (2011), criticize transition management literature for lacking acknowledgement of existing and pre-existing political conditions and dynamics. Recently, Ramos-Mejía et al. (2017) called for new thinking on how poverty alleviation can be realised in the context of the institutional context. They view the context for innovation in governance terms to be a loose 'layered' scenario where different institutional 'pockets' can be present or absent at various degrees. While there will be pockets of ill-functioning institutions, where social exclusion patterns can prevail, there should also be pockets of 'better-functioning' institutions, where social inclusion is pursued (Ramos-Mejía et al., 2017). From the findings of this study we contend that Fajardo's formalization of new governance arrangements emerging during the 1990s under the Genesis regime as civic pacts represented pockets of 'better-functioning' institutions. Supported by the articulation of a clear vision for Medellín this also helped to shift thinking among political and business elites that lent support to Fajardo's determination to address social exclusion. We link the pacts as transition arenas in this respect to Smith and Raven's (2012) ideas on stretch and transform empowerment. The institutionalization of reflexive forms of governance that emerged during the 1990s as civic pacts created new norms and routines. The pacts at a community level were not subordinated by the 
Rejuvenation regime but were contributors to transitioning from the Genesis to the Rejuvenation regimes.

Advocates in the pacts presented realistic resolutions to socio-economic issues around for example education; with the formalization of governance practices in the pacts becoming accepted by city elites in bringing change about. The pacts were formally integrated with city level socio-economic priorities to address social exclusion through the city vision. As 'stretch and transform' transition arenas the pacts created new capabilities and attracted resources that empowered participation on the shape of socio-economic priorities in particularly education. Fajardo emphasized the need for the pacts to engender transparency, co-responsibility and open communication between actors. Crucially, the pacts received funding and support from influential private firms such as Empresas Publicas de Medellín (EPM). Given the reach and legitimizing capacity of EPM to the transition arenas, they have been referred to by RamosMejía et al. (2017) as systemic intermediaries (see also for e.g. Iyang et al., 2014). EPM were complemented by formalized participatory budgeting arrangements that devolved municipal budgetary decisions to communities. In these radically new institutionalized transition arenas Medellín's citizens were empowered to experiment, plan and implement initiatives in education and infrastructure for example to address social exclusion in their neighbourhoods; creating a powerful incentive for collaboration with city authorities, private firms and other relevant stakeholders.

5.2 The development of shared socio-economic expectations among actors on tackling urban social exclusion

Wood and Gough (2006), note that while poverty eradication and social inclusion is a universal goal, policy solutions need to be context-specific means to achieve it through legitimated institutional settings. We found from this study that transition arenas are 
important to this to the extent that citizens of a city individually and collectively can develop shared socio-economic expectations. The emergence of new participatory platforms representative of transition arenas such as Foros Comunales (community fora) and Compromiso Ciudadano (citizen engagement) during the 1990s helped in drawing together citizens, business leaders, city authorities and other relevant stakeholders as part of a process of socio-economic change. This was supported formally by national initiatives to devolve power to the city level led by President Gaviria in 1990. Fora and Compromiso Ciudadano are examples of radically new reflexive governance arrangements for citizens to articulate and discuss ways to create a more inclusive urban society.

Given the diverse interests represented this posed a challenge. The recognition of the city's violence and dysfunctionality at one important level created the desire among these actors to collaborate in order to enact socio-economic transition. Between 1993-1995 the level of violence in Medellín led to rose to such levels that business and political elites were more open to transition arenas that included citizens on their terms. 'Citizens leadership' and the historical social debt felt to be owed by elites came together in this regard. An important factor in establishing the legitimacy of these radically new governance platforms was the support of the United Nations Development Programme (UNDP) (Maclean, 2014). Crucially, they also began to draw support from community groups and NGOs that previously were seen to be against city authorities and institutions. Social exclusion became prominent agenda items for these actors as well as political and business elites in the city. This provided an opportunity to articulate and mutually adapt socio-economic expectations. Arguably a consensus was formed around policy items such as education, employment and infrastructure that was central to the social urbanism of Fajardo in tackling social exclusion and to transitioning from the Genesis regime of the 1990s to the Rejuvenation regime of the 2000's. 
Swyngedouw (2005) criticizes governance theory pertaining to assuring representativeness, legitimacy and accountability when city authorities devolve accountability. Voß and Bornemann (2011) state that designs for reflexive governance need to take greater account of the politics of learning. Critical to this in their view is how to provide safeguards for vulnerable communities against domination by powerful elites in cities who seek to further a narrow socio-economic agenda. The study findings reveal that under Fajardo's Mayoral tenure the reflexive governance arrangements emerging during the 1990 s were institutionalized by civic pacts in a manner that upheld democratic principles in and through governance. Integral to the pacts in this respect was the city vision creating shared socioeconomic expectations among heterogeneous actors (city authorities, community groups, private firms) on tackling social exclusion. Concurring with Weber and Rohracher's (2012), vision-building was important to smoothing out competing interests and potential dominance by elite interests in civic pacts, acting as a coordination device "for collective sensemaking, imaginization and enactment" (Weber and Rohracher, 2012: 1044). The articulation of a clear city vision combined political, intellectual and moral leadership with a flow of material rewards that aided in the translation of diverse city interests into effective agency on the ground to tackle social exclusion (see for example the work of Sum, 2005). The vision aided reflexive arrangements in the civic pacts 'softening' the emphasis on consensus as a source of legitimacy by acknowledging plurality. This allowed previously marginalized communities to feel more confident in raising their unique socio-economic needs against competing interests and assuming co-responsibility with them for socio-economic development.

The institutionalization of processes of mutual adaptation in pacts as transition arenas on various socio-economic dimensions represented new ways to work with conflict and power in the process of experimentation and learning among actors with diverse backgrounds and interests. Creative response to 21 st Century city visions needs the harnessing of imagination 
in vulnerable and marginalized urban communities to enable socio-economic change over the long term. Medellín's vision under Fajardo's tenure arguably provided a platform for private firms alongside communities, poiliticians and other stakeholders to collaboratively imagine and experiment with new institutionalized forms of reflexive governance. Reflexive governance practices should progressively shift the balance of structure and agency in favor of citizens' capacity and decision-making that acknowledges diversity of perspectives and related interests on socio-economic dimensions that are relevant and need to be accommodated. By allowing citizens through civic pacts to take full credit for the success of initiatives to address social exclusion integrated with the city vision, a powerful incentive for cooperation was created.

A growing consensus has formed around the need for private firms including global corporations and governments to accept moral responsibility for social welfare and individual interests in their economic transactions (Aba-Rao, 1993; Hill et al. 2007). The idea of 'Participatory Cities' for the 21 st century is currently attracting the interest of leading multinational corporations such as BMW. Participatory relationships require global corporations to share information and their experience to help inform the socio-economic development policies of host governments and communities. In many respects it is in corporations' interests to do this as technology is making participation hegemonic - from prosumers to crowdsourcing, from collaborative practices to civic media - with increasing redefinition of the notion of participation itself. BMW's Guggenheim Lab embraced this as part urban think tank, part community centre and public gathering space. The Lab's key goal was to explore new ideas, experiment, and ultimately create forward-thinking visions and projects for city life. Reflecting on the areas of urbanism, architecture, art, design, science, technology, education, and sustainability, a key conclusion of the Lab is the need for 'Participatory Cities': making urban environments more responsive to people's ever-changing needs, 
making people feel more at ease in urban environments, and finding a balance between notions of modern comfort and the urgent need for environmental, social and economic responsibility. Recent research, for example, points to the success of collaboration in cities between public agencies, the private sector and local communities to systemically re-engineer their built environment and urban infrastructure in response to climate change and resource constraints (Eames et al., 2013).

Empresas Publicas de Medellín (EPM) was a critical corporate actor in supporting the development of shared socio-economic expectations among actors on tackling social exclusion. EPM is an interesting but progressive anomaly, operating as a private firm and paying taxes it is owned by the City of Medellín who pay for the utility services it offers like any other customer. EPM's public ownership and key role in extending infrastructure to the most deprived neighbourhoods in the city made it uniquely qualified to support the civic pacts and participatory budgeting initiatives as radically new and institutionalized forms of reflexive governance. The legitimacy provided through EPM's engagement encouraged other private firms to put social exclusion and by extension social responsibility higher up their agendas. Alongside EPM Renowned Colombian architects such as Rogelio Salmona with engineering and construction firms collaborated in civic pacts on high-status signature architectural designs for new schools, libraries and Cedezo spaces located in their neighborhoods. In the Santo Domingo neighborhood, the impressive new schools built and the, now famous, Parque Biblioteca España library collocated with transport infrastructure developments such as MetroCable, creating a new narrative around the idea of 'give the best to the poorest'. This provided the dignity and pride of place for citizens that Fajardo's social urbanism sought to bring.

\section{Conclusion}


This study sought to uncover the link between governance as an innovation process and socio-economic regime transition in a city towards a more equitable urban society. While Medellín continues to have problems, socio-economic transformation has significantly affected the lives of people that suffered the most during the 1980's and 90's. The integration of governance with transition management thinking offers potential for further research will be needed to develop our understanding. While integration of concepts of governance and transition management in this study demonstrates the political factors involved in socioeconomic change in a city, the challenge is in applying idealized conceptual terms to empirical research in cities around the world. This will no doubt be overcome by future research and should raise more interesting questions, particularly with regards to the fast developing concept of Smart Cities. The integration of governance and transition management provides a particularly interesting basis to interrogate the Smart City concept. Specifically, to judge if from a policy perspective it can be for the good of citizens at large in cities and not just serve the interests of narrow technology sector elites that stand to benefit from its further roll-out around the world. 


\section{References}

Alkemade, F., Hekkert, M.P. and Negro, S.O. (2010). Transition policy and innovation policy: friends or foes? Environmental Innovation and Societal Transitions, 1, 125 129.

Amba-Rao, S.C. (1993). Multinational corporate social responsbility, ethics, interactions and Third World Governments: An agenda for the 1990's. Journal of Business Ethics, 12, 553-572.

Avelino, F. and Rotmans, J. (2009). Power in transition: an interdisciplinary framework to study power in relation to structural change. European Journal of Social Theory, 12 (4), 543-569.

Bahl, V. (2011). Murder Capital to Modern Miracle? The Progression of Governance in Medellín, Colombia, Development Planning Unit, University College London

Baptista, R. (2003). Productivity and the density of local clusters. In: Brocker, J. Soltwedel, R. (Eds.) Innovation Clusters and Interregional Competition (Advances in Spatial Science), Springer, Berlin Heidelberg, pp. 163-182.

Betancur, J.J. (2007). Approaches to regularization of informal settlements: The case of PRIMED in Medellin, Colombia. Global Urban Development, 3, 1-15.

Bergek, A., Jacobsson, S., Carlsson, B., Lindmark, S. and Rickne, A. (2008) Analyzing the functional dynamics of technological innovation systems: A scheme of analysis. Research Policy, 37, 407-429.

Berkhout, F. (2006). Normative expectations in systems innovation. Technology Analysis and Strategic Management, 18, 299-311.

Bottazzi, L. and Peri, G. (2003). Innovation and spillovers in regions: Evidence from European patent data, European Economic Review, 47, 687-710.

Darrot, C., Diaz, M., Tsakaliou, E. and Zagata, L. (2015). 'The missing actor': alternative agri-food networks and the resistance of key regime actors. In: Sutherland, L-A., Darnhofer, I., Wilson, G.A., Zagata, L. (Eds.), Transition Pathways Towards Sustainability in Agriculture: Case Studies from Europe. CABI, Wallingford, UK. Pp. 145-158.

Eames, M., Hunt, M., Dixon, T. and May, T. (2013). City futures: exploring urban retrofit and sustainable transitions. Building Research and Information, 41, 504-516.

Elzen, B., van Mierlo, B. and Leeuwis, C. (2012). Anchoring of innovations: Assessing Dutch efforts to harvest energy from glasshouses. Environmental Innovation and Societal Transitions, 5, 1-18. 
Fischer, M., Frohlich, J., Gassler, H. and Varga, A. (2001). The role of space in the creation of knowledge in Austria - an exploratory spatial analysis. In: Fischer, M., Frohlich, J. (Eds.), Knowledge, Complexity, and Innovation Systems. Springer, Berlin, pp. 124145.

Gabrys, J. (2014). Programming environments: environmentality and citizen sensing in the smart city. Environment and Planning D: Society and Space, 32, 30-48

Garud, R. and Karnoe, P. (2003). Bricolage versus breakthrough: distributed and embedded agency in technology entrepreneurship. Research Policy, 32, 277-300.

Geels, F.W. (2002). Technological transitions as evolutionary reconfiguration processes: a multi-level perspective and a case-study. Research Policy, 31, 1257-1274.

Geels, F.W. (2004). From sectoral systems of innovation to socio-technical systems - insights about dynamics and change from sociology and institutional theory. Research Policy, 33, 897-920.

Geels, F.W. (2005). Processes and patterns in transitions and system innovations: Refining the co-evolutionary multi-level perspective. Technological Forecasting \& Social Change, 72, 681-696.

Geels, F.W. and Kemp, R. (2007). Dynamics in socio-technical systems: typology of change processes and contrasting case studies. Technology in Society, 29, 441-455.

Geels, F.W. and Schot, J.W. (2007). Typology of sociotechnical transition pathways. Research Policy, 36, 399-417.

Geels, F.W. and Schot, J.W. (2010). A tyology of of transition pathways. In Grin, J., Rotmans, J., Geels, F.W. Loorbach, D. (Eds.), Transitions to Sustainable Development. New Directions in the Study of Long Term Transformative Change. Routledge, London. pp. 54-79.

Geels, F.W. (2011). The multi-level perspective on sustainability transitions: Responses to seven criticisms. Environmental Innovation and Societal Transitions, 1, 24-40.

Grin, J. (2006). Reflexive modernisation as a governance issue, or designing and shaping restructuration. In: VoB, J-P., Bauknecht, D., Kemp, R. (Eds.), Reflexive Governance for Sustainable Development. Edward Elgar, Cheltenhem, pp. 31-56.

Guy, S. and Marvin, S. (1999). Understanding sustainable cities: competing urban futures. European Urban and Regional Studies, 6, 268-275.

Guy, S., Marvin, S., Medd, W. and Moss, T. (2011). Shaping Urban Infrastructures: Intermediaries and the Governance of Socio-Technical Networks, London: Earthscan.

Hendriks, C.M. and Grin, J. (2007). Contextualizing reflexive governance: the politics of Dutch transitions to sustainability. Journal of Environmental Policy and Planning, 9, 333-350. 
Hill, R.P., Ainscough, T., Shank, T. and Manullang, D. (2007). Corporate social responsibility and socially responsible investing: A global perspective. Journal of Business Ethics, 70, 165-174.

Hodson, M., Marvin, S., Robinson, B. and Swilling, M. (2012). Reshaping urban infrastructure. Journal of Industrial Ecology, 16, 789-800.

Hölscher, K., Wittmayer, J.M. Avelino, F. and Giezen, M. (2017). Opening up the transition arena: An analysis of (dis)empowerment of civil society actors in transition management in cities. Technologial Forecasting and Social Change, Available online 19 May 2017.

Hylton, F. (2007). Medellin's makeover. New Left Review, 44, 70-89.

Van Lente, H. (2003). Roles of systemic intermediaries in transition processes. International Journal of Innovation Management, 7, 247-279.

Johnson, B. (2008). Cities, systems of innovation and economic development. Innovation: Management Policy \& Practice, 10, 146-155.

Kemp, R., and Loorbach, D. (2006). Transition management: a reflexive governance approach. Pages 103-130 in J. P. Voß, D. Bauknecht, and R. Kemp, editors. Reflexive Governance for Sustainable Development. Edward Elgar, Cheltenham, UK.

Kemp, R., Rotmans, J. and Loorbach, D. (2007). Assessing the Dutch energy transition policy: how does it deal with dilemmas of managing transitions? Journal of Environmental Policy and Planning, 9, 315-331.

Kuhlmann, S., Shapira, P. and Smits, R. (2010). Introduction. A systemic perspective: the innovation policy dance. In: Smits, R., Kuhlmann, Shapira, P. (Eds.). The Theory and Practice Innovation Policy: An International Research Handbook. Edward Elgar, Cheltenham, pp. 1-22.

Loorbach, D. (2007). Transition Management: New Mode of Governance for Sustainable Development. International Books, Utrecht.

Loorbach, D. and Rotmans, J. (2010). The practice of transition management: examples and lessons from four distinct cases. Futures, 42, 237-246.

Madanipour, A., Cars, G. and Allen, J. (1998). Social Exclusion in European Cities: Processes, Experiences, and Responses. Jessica Kingsley: London.

Marceau, J. (2008). Introduction: Innovation in the city and innovative cities. Innovation: Management, Policy and Practice, 10, 136-145.

Maclean (2014). 'The Medellín Miracle'.The politics of crisis, elites and coalitions. Developmental Leadership Program, 24, 1-69. 
Meadowcroft, J. (2009). What about the politics? Sustainable development, transition management, and long term energy transitions. Policy Sciences, 42, 323-340.

Mossberger, K. and Stoker, G. (2001). The evolution of urban regime theory: The challenge of conceptualization. Urban Affairs Review, 36, 810-835.

Mowery, D.C., Nelson, R.R. and Martin, B.R. (2010). Technology policy and global warming: Why new policy models are needed (or why putting new wine in old bottles won't work). Research Policy, 39, 1011-1023.

Painter, J. (2009). Governance. In: Gregory. D. Johnston, Pratt, R., Watts, M.J. and Whatmore, S. eds. 2009. The Dictionary of Human Geography: west Sussex, Wiley, 312-313.

Pantazis, C., Gordon, D. and Levitas, R. (2006). Poverty and Social Exclusion in Britain, The Policy Press, Bristol.

Ramos-Mejía, M., Franco-Garcia, M-L., Jauregui-Becker, J.M. (2017). Sustainability transitions in the developing world: Challenges of sociotechnical transformations unfolding in contexts of poverty. Environmental Science and Policy, Article in Press

Raven, R. (2007). Co-evolution of waste and electricity regimes: multi-regime dynamics in The Netherlands (1969-2003). Energy Policy, 35, 2197-2208.

Raven, R. and Geels, F.W. (2010). Socio-cognitive evolution in niche development: comparative analysis of biogas development in Denmark and The Netherlands (19732004). Technovation, 301, 87-99.

Rip, A. and Kemp, R. (1998). Technological change, in: S. Rayner \& E.L. Malone (eds), Human Choice and Climate Change, Columbus, Ohio: Battelle Press. Volume 2, $327-$ 399.

Simmie, J. (2003). Innovation and urban regions and national and international nodes for the transfer and sharing of knowledge, Regional Studies, 37, 607-620.

Smith, A., Stirling, A. and Berkhout, F. (2005). The governance of sustainable sociotechnical transitions. Research Policy, 34, 1491-1510.

Smith, A. (2007). Translating sustainabilities between green niches and socio-technical. Technology Analysis and Strategic Management, 19 (4), 427-450.

Smith, A. and Raven, R. (2012). What is protective space? Reconsidering niches in transitions to sustainability. Research Policy, 41, 1025-1036.

Smith, A. and Stirling, A.C. (2010). The politics of social-ecological reslience and sustainable socio-technical transitions. Ecology and Society, 15, 11. 
Smith, A., VoB, J-P. and Grin, G. (2010). Innovation studies and sustainability transitions: the allure of the multi-level perspective and its challenges. Research Policy, 39, 435448.

Sutherland, L-A., Peter, S. and Zagata, L. (2015). Conceptualising multi-regime interactions: The role of the agriculture sector in renewable energy transitions. Research Policy. 44, 1543-1554.

Swyngedouw, E. (2005). Governance innovation and the citizen: The Janus face of governance-beyond-the-State. Urban Studies, 42, 1191-2006

Tödtling, F. and Trippl, M. (2005). One size fits all? Towards a differentiated regional innovation approach. Research Policy, 34, 1203-1219.

Voß, J. P. (2007a). Innovation processes in governance. The development of emissions trading as a new policy instrument. Science and Public Policy, 34, 329-343

Voß, J. P., Newig, B. Kastens, J. Monstadt, J. and Nölting, B. (2007b). Steering for sustainable development: a typology of problems and strategies with respect to ambivalence, uncertainty and distributed power. Journal of Environmental Policy and Planning, 9, 193-212.

Voß, J. P. Smith, A. and Grin, J. (2009). Designing long-term policy: rethinking transition management. Policy Sciences, 42, 275-302

Voß, J. P. and Bornemann, B. (2011). The politics of reflexive governance: Challenges for designing adaptive management and transition management. Ecology and Society, 16, 9 .

Walker, G. and Shove, E. (2007). Ambivalence, sustainability and the governance of sociotechnical transition. Journal of Environmental Policy and Planning, 9, 213-225.

Weber, K.M. and Rohracher, H. (2012). Legitimizing research, technology and innovation policies for transformative change: Combining insights from innovation systems and multi-level perspective in a comprehensive framework. Research Policy, 41, 10371047.

Wood, G. and Gough, I. (2006) A comparative welfare regime approach to global social policy. World Devolpment, 34, 1696-1712.

Yin, R. K. (2003). Case Study Research: Design and Methods (3rd ed.). Thousand Oaks, CA: Sage. 